\title{
Application of Immobilized Cells and Enzymes in the Food Industry
}

\section{Judit Krisch, Erika Beáta Kerekes, Miklós Takó and Csaba Vágvölgyi}

\section{CONTENTS}

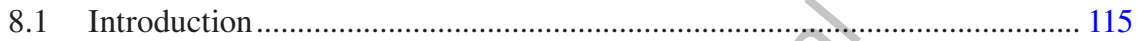

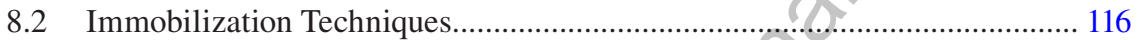

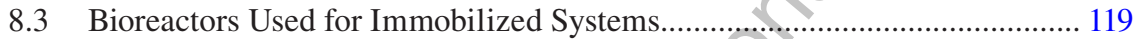

8.4 Properties of Immobilized Cells and Enzymes _......................................... 119

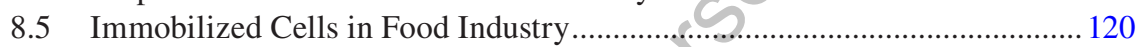

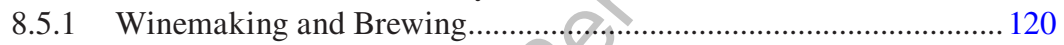

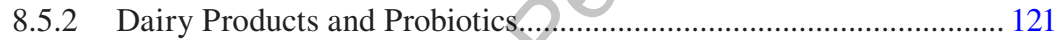

8.5.3 Vinegar Production.......................................................................... 122

8.5.4 Enzyme Production with Immobilized Cells .................................. 122

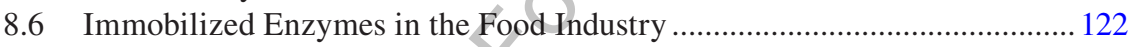

8.6.1 Starch Industry and Production of Sweeteners .............................. 123

8.6.2 Production of Prebiotics ................................................................. 123

8.6.3 Immobilized Enzymes in the Production of Beverages .................... 124

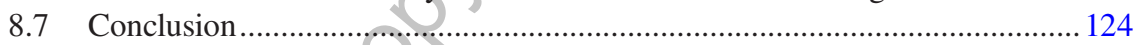

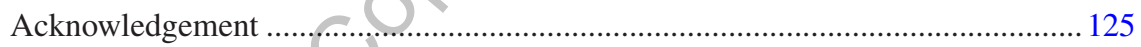

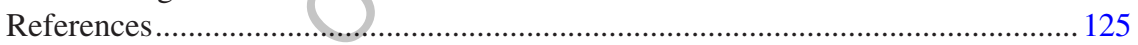

\subsection{Introduction}

Immobilization of whole cells, cell debris, purified and crude enzymes, aroma compounds, nutraceuticals, active agents of medicaments or cosmetics and vitamins is an everyday practice in pharmacy, environmental protection, cosmetics, etc. With the aid of nanotechnology, fine delivery systems controlling the release of the immobilized compounds were developed. In food industry, cells and enzymes are usually used directly in food processing and some of them become a part of the food. Therefore, a very careful selection of immobilization materials and techniques must be done. Immobilization offers many advantages compared to traditional processes, and can help design new, healthy foods using environment friendly methods to satisfy the expectations of the consumers. In this chapter, immobilization techniques already used in the food sector or in the developing phase are presented with examples of microbial cells and enzymes suitable for this application. 


\subsection{Immobilization Techniques}

Immobilization of whole cells or enzymes means fixation to a support, or supportfree cross-linking of aggregates. In the food industry, one has to be especially careful with choosing the right support and immobilization technique because of food safety considerations. The support and solvents used cannot be toxic or cause any harm to the consumer. From the industrial point of view, a good support is cheap, renewable and the immobilization is feasible. The support shall protect the immobilized cell or enzyme from the shear forces and harsh environmental circumstances arising during the fermentation process in a tank reactor. It must also be resistant to microbiological degradation.

Support associated immobilization techniques include adsorption, entrapment or encapsulation and covalent binding, the latter being used more for enzymes than cells. In most cases, immobilized cells have to retain their viability for a successful operation but covalent linking can lead to cell wall injuries and limited survival of the cells.

Adsorption is the most simple and cheap immobilization technique where the cells or enzymes attach to inorganic or organic surfaces via dipole-dipole and hydrophobic interactions, Van der Waals forces or hydrogen bonding (Groboillot et al. 1994; Contesini et al. 2013; Rouf et al. 2017). In most cases, preformed, porous materials are used such as cellulose beads or fibers, ceramics and silica materials (Groboillot et al. 1994; Krisch et al. 1995; Szajáni et al, 1996). In Figure 8.1 (a and b), the cross section and outer surface of a preformed cellulose bead can be seen. Large cavities within the beads and microspores and rough surface on the outer shell offer sites for adhesion. Immobilization is usually performed in the fermenter by adding the support and cells or enzymes at the same time and after adsorption, the nonadhered cells are washed out (Groboillot et al. 1994; Elakkiya et al. 2016). Adhered cells usually form biofilms on the surface and in the cavities of the support, which results in enhanced resistance against toxic materials and $\mathrm{pH}$ changes during fermentation (Krisch and Szajáni 1996). In Figure 8.2 (a and b), Acetobacter aceti and Saccharomyces cerevisiae biofilms formed on cellulose beads can be seen. Adsorbed enzymes show enhanced thermal stability (Contesini et al. 2013). Disadvantage of this technique is the easy detachment from the surface of the support on changing environmental conditions ( $\mathrm{pH}$, ionic strength, temperature) and wash out from the reactor (Groboillot et al. 1994; Contesini et al. 2013; Rouf et al. 2017). Washed-out cells or enzymes can contaminate the product.

By entrapment, cells and enzymes are packed into a gel matrix usually forming beads with diameters between 1 and $5 \mathrm{~mm}$. Entrapment and gel formation occurs at the same time by adding the cells or enzymes to the liquid gel followed by gelation and beads formation. The gel-forming agent is mostly a polysaccharide and gel formation occurs by temperature changes as in the case of agar, agarose, $\kappa$-carrageenan and gellan; or by ionic cross-linking with multivalent cations in the case of alginate and chitosan (Groboillot et al. 1994; Elakkiya et al. 2016). These polysaccharides have the advantages of being biocompatible and not degradable by the entrapped microbes. Entrapment results in enhanced mechanical and chemical stability but mass transfer limitations of the substrate into the bead can lead to decreased activity (Rouf et al. 2017). The polysaccharides are used in the concentration of $1 \%-4 \%$ to 
(a)
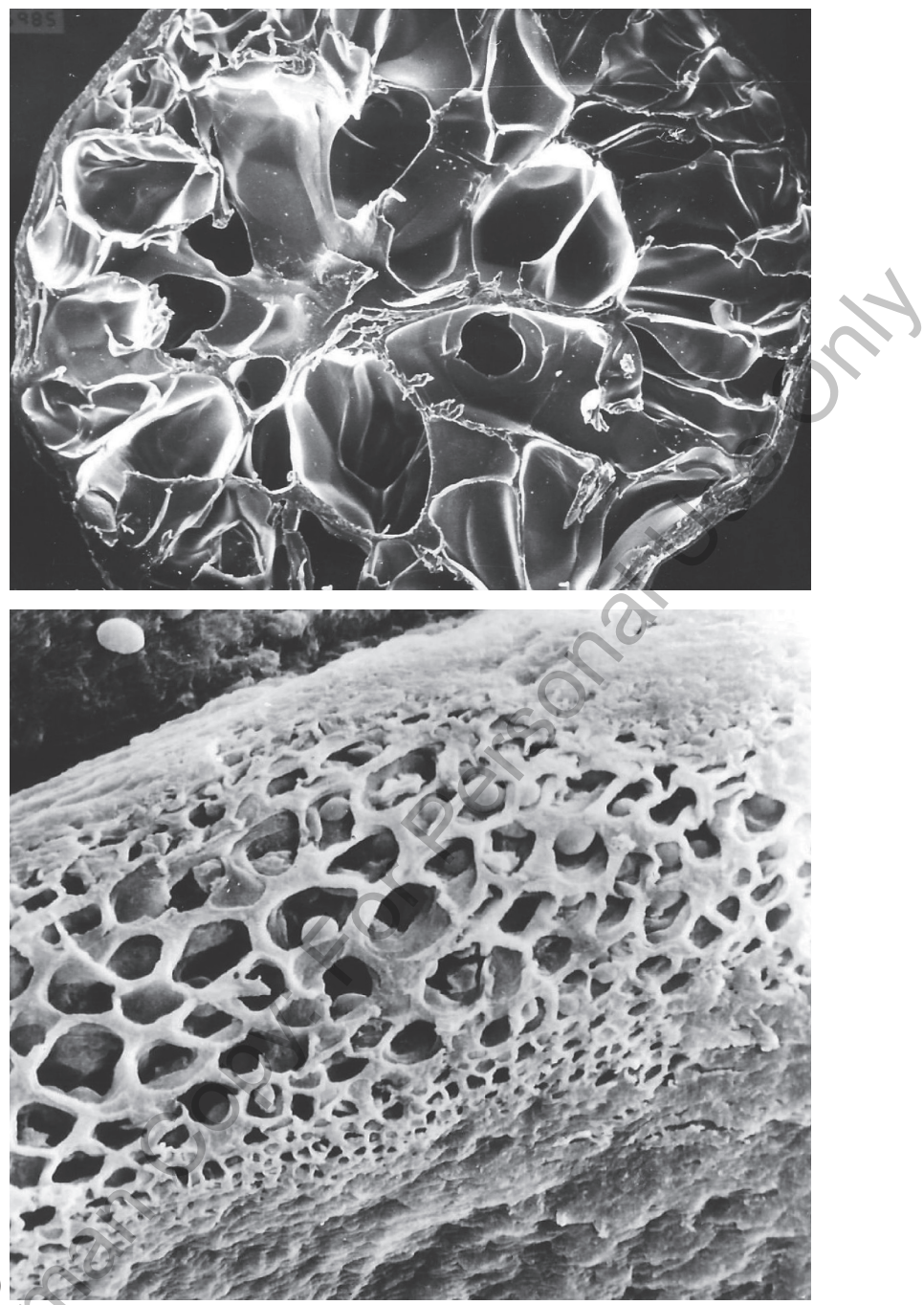

FIGURE 8.1 Scanning electron microscope images of preformed cellulose beads. (a) Cross section of the bead (35X); (b) surface with micro-pores. Yeast (S. cerevisiae) cells grow in the pores (1000X).

avoid or decrease these diffusion limitations. In the presence of chelating agents or by changing the $\mathrm{pH}$, ionotropic gels will lose integrity and the cells or enzymes will be released from the matrix. Therefore, proper conditions for these gels, viz. continuous presence of the gel-forming cation, are required. Agar and carrageenan gels have less mechanical strength, but formation is simpler and does not need cations in the fermentation broth (Groboillot et al. 1994). The choice of gelation material is based on the fermentation process and the cells or enzymes to be entrapped. Cells usually grow near to the surface of the gel beads and can escape from it. To avoid or reduce cell release from the beads, sometimes a shell is formed on the outer surface by dipping the 


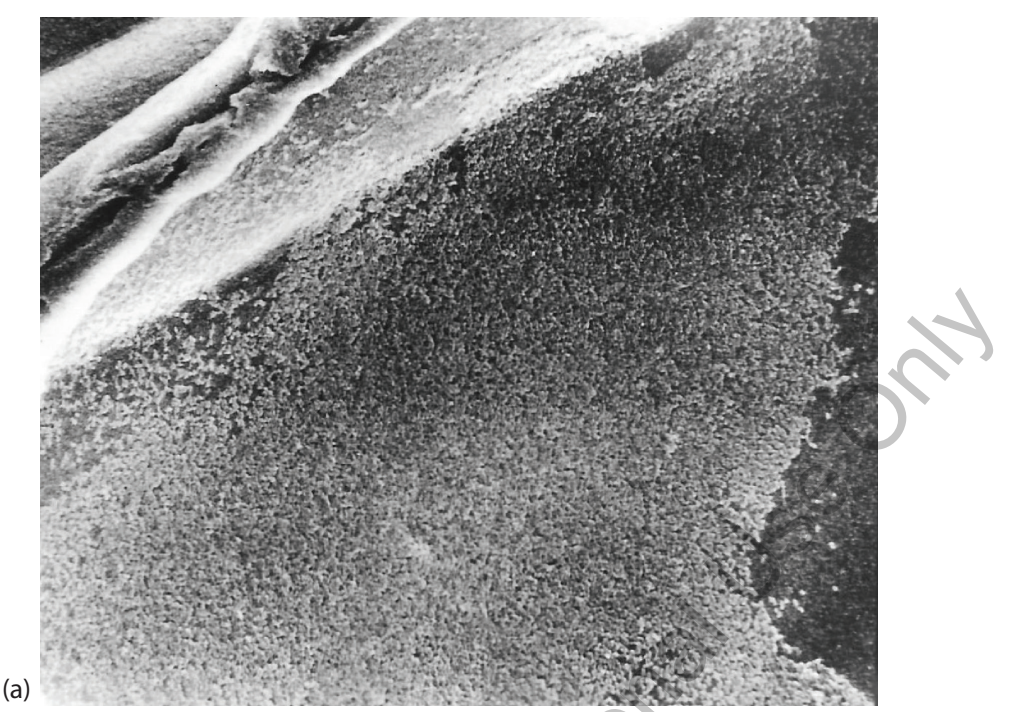

(b)

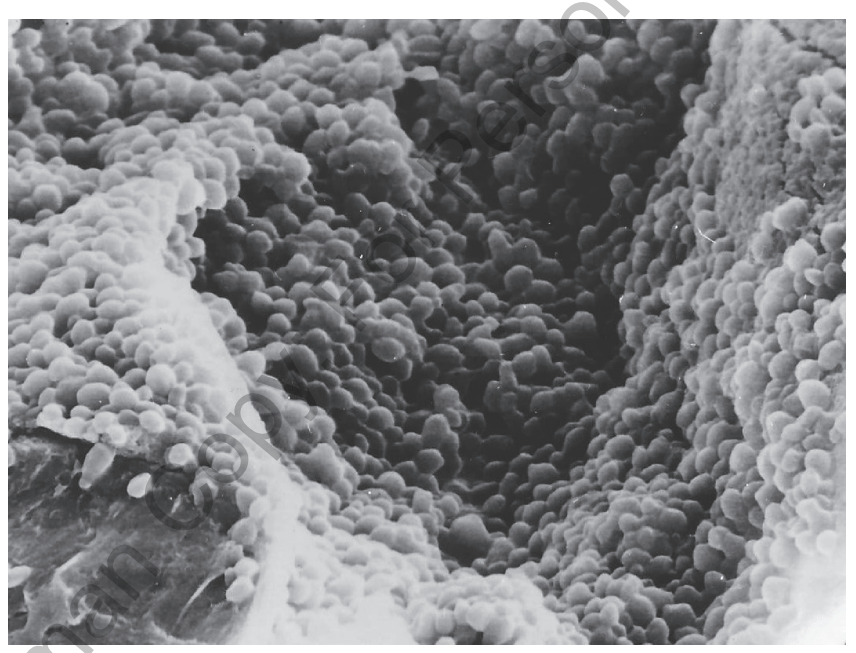

FIGURE 8.2 (a) Biofilms on the inner walls of cavities in preformed cellulose beads-Acetobacter aceti (800X); (b) Biofilms on the inner walls of cavities in preformed cellulose beads-S. cerevisiae (700X).

beads in a coating solution containing the same or another polymer (Groboillot et al. 1994). Encapsulation is an alternative technology to entrapment with the advantage of no leakage of the content and higher loading capacity (Kosseva, 2011). Encapsulation is made by emulsification creating a wall around the cell(s) or enzyme(s). Examples for encapsulation are liposomes with one or two layers of phospholipids (Gibbs et al. 1999). Liposomes can range from nanometres to micron size and are non-toxic and acceptable for food applications. Self-assembling proteins like $\alpha$-lactalbumin of milk can form nanotubes capable of immobilization of enzymes (Weiss et al. 2006; Sozer and Kokini 2009). In this aspect, nanotechnology offers new tools for immobilization. 
Support-free aggregates of yeast cells can be formed by natural flocculation, which is an important process in separating yeast cells from beer (Genisheva et al. 2014). Aggregation, especially in the case of enzymes, can be forced by using cross-linking agents such as glutaraldehyde and bis-isodiacetamide (Abdelmajeed et al. 2012; Rouf et al. 2017). The large three-dimensional structure of enzyme aggregates multiplies the active area for a faster reaction. The criterion for successful cross-linking or covalent binding of an enzyme to a support is that sites not involved in the reaction are chemically bound. Covalent binding can enhance the rigidity and thus the stability of the enzyme structure but on the other hand, this rigidity can inhibit the free movement of the enzyme resulting in decreased activity (Rouf et al. 2017). A special type of enzyme immobilization is when non-viable whole cells are immobilized. In this case, multiplestep reactions can be implemented where more enzymes are needed at the same time, like in aspartate production for the sweetener aspartame (Johnson-Green 2002).

\subsection{Bioreactors Used for Immobilized Systems}

Immobilization allows continuous production without loss of the biocatalyst. The type of bioreactor used for immobilized systems depends on the mass transfer requirements and easy removal of product. Stirred tank reactors can be used for batch or continuous production; in the latter case, often more reactors are connected to each other to enhance productivity. Shear forces in this reactor can damage the support material, leading to loss of the biocatalyst. The packed bed reactors are commonly used in the industry. In these reactors, the biocatalysts are packed into a column and the fermentation broth flows through the bed. Anaerobic conditions can easily be achieved, for example, for ethanol fermentation. Packed bed reactors are cheap and simple to operate, but some problems with gas bubble formation, product inhibition at upper layers, and compaction of the bed can occur (Groboillot et al. 1994; Kosseva 2011; Rouf et al. 2017). Fluidized bed reactors are used for processes where oxygenation is needed. The added gas moves the biocatalyst and mixes the fermentation broth. In this reactor, substrate inhibition is minimal owing to the good mixing, and heat transfer is excellent (Rouf et al. 2017). Different variations of these bioreactors were designed to solve the problems arising during operation.

\subsection{Properties of Immobilized Cells and Enzymes}

In many cases immobilization brings higher productivity, shorter fermentation time, and higher product yield. Immobilized cells and enzymes are physically protected by the support from the changing conditions in the environment. Immobilized biocatalysts tolerate temperature and $\mathrm{pH}$ changes better, and are less sensitive to substrate or product inhibition (Krisch and Szajáni 1996, 1997, Mitropoulou et al. 2013). Advantages of immobilized systems over traditional fermentation using free cells or enzymes cannot be explained only with the protective effect of the support matrix. Changes in the physiology of immobilized cells (Willaert 2011; Zur et al. 2016) as well as changes in the conformation of immobilized enzymes (Flores-Maltos et al. 2011) also contribute to the enhanced activity. Adsorbed cells usually form biofilms on the surface of the support, which is a multi-step process. The first adhesion of cells 
is the result of different interactions between the surface of the cell and the support causing reversible attachment followed by the reinforcement of the bonding resulting in irreversible connection. Attached cells began to form micro-colonies and produce extracellular matrix that connects the cells to each other and the surface (Kerekes et al. 2015). During biofilm maturation, a three-dimensional structure will be formed in which different layers can be found causing physiological, structural and mass transfer heterogeneity (Sutherland 2001; Zur et al. 2016). In the matured biofilm, cells from the top layer can detach and go into the fermentation broth.

In a biofilm, cell to cell or cell to surface interactions depend on the expression of special proteins such as the Flo protein family in S. cerevisiae. Regulation of the FLO genes contribute to the switch from non-adhesive planktonic cells to adhesive cells (Bojsen et al. 2012).

The extracellular matrix called EPS (extracellular polymeric substances) consists of polysaccharides, proteins, nucleic acids and lipids. This EPS plays a crucial role in the adhesion of biofilms, adsorbs water and nutrients from the environment, and represents a protective barrier against antimicrobial agents. Increased resistance of the cells in the biofilm to inhibitors may be the consequence of horizontal gene transfer in this EPS. Compositional changes or reorganization of cell wall or membrane (e.g. higher rate of unsaturated lipids) are also responsible for enhanced stress tolerance (Zur et al. 2016).

Entrapped cells in a gel are surrounded by the matrix and have no direct connection to the environment unlike adsorbed cells. Cells within the matrix can enjoy stronger protection than adsorbed cells (Krisch and Szajáni 1997). In the gel matrix, oxygen and nutrient diffusion rate decreases gradually, and due to the phenomenon, the cells migrate close to the outer surface of the bead and form large colonies (Groboillot et al. 1994). Owing to the diffusion limitations, cells grow slowly in the beads, which in turn leads to higher plasmid stability (Willaert 2011).

As can be seen from the aforementioned examples, the protective effect of the support and changes in the cell physiology contribute to the better performance of immobilized biocatalysts over the free ones.

\subsection{Immobilized Cells in Food Industry}

\subsubsection{Winemaking and Brewing}

In traditional winemaking, the natural microflora of the grapes, remaining only $S$. cerevisiae at the end, performs alcoholic fermentation of grape must. Nowadays specific, dry yeasts (mostly strains of $S$. cerevisiae) with different enzyme activities for the liberation of aroma compounds are added to start the fermentation. Winemaking is usually carried out in batch reactors, although continuous processes using immobilized cells resulted in higher productivity and high product yields. Packed bed reactors have the advantage to create anaerobic conditions ideal for ethanol fermentation. Support materials for cell immobilization in winemaking have to fulfil food safety considerations and must be non-toxic, food-grade materials. A lot of different techniques and materials have been used for yeast cell immobilization but considering the economic and food safety aspects, dried and sterilized plant materials remaining after juice pressing like grape stems and skins seem to be the best solution for 
adsorption of yeast cells. Consumers will also accept winemaking processes where only natural materials are used (Genisheva et al. 2014).

During maturation of wine, malolactic fermentation can take place where lactic acid bacteria convert L-malic acid to L-lactic acid by decreasing the acidity of the wine. Using immobilized Oenococcus oeni (formerly Leuconostoc oenos) doubled the degradation rate of malic acid, resulting in a milder taste in the wine (Genisheva et al. 2014).

In sparkling wines and champagnes, the removal of lees takes a lot of time. Using coated alginate beads for the immobilization of champagne yeasts makes it easy to separate the cells from the liquid (Genisheva et al. 2014).

Continuous beer fermentation was made by immobilizing brewer's yeasts on cheap plant wastes like corncobs and spent grain, resulting in "quite acceptable" beer with unbalanced flavour compared to a traditional lager. By refining process parameters, the authors hoped to achieve better aroma and taste competing with traditional beer. Immobilization has shortened the fermentation time, reducing the costs of beer making (Brányik et al. 2005).

\subsubsection{Dairy Products and Probiotics}

Dairy products like yoghurts and cheeses are consumed in large quantities owing to their good taste and digestibility and health-promoting effects. Lactic acid bacteria (LAB) play a key role in the fermentation of milk to various products by coagulation of milk proteins through lactic acid production. Starters are mainly used in frozen form and are added directly to the milk. Problems with starters are arising from plasmid loss, sensitivity to bacteriophages, and contamination. Plasmid encoded products of LAB are involved in the degradation of the milk protein casein, production of lactic acid and flavour compounds. Plasmids are also responsible for production of bacteriocin and EPS, and for resistance to bacteriophages (Cui et al. 2015). Therefore, plasmid loss can cause starter failure. Immobilization of LAB improved plasmid stability, bacteriocin and EPS production, and resistance to bacteriophages (Doleyres and Lacroix 2004). Continuous production of single or mixed strains of LAB starters can be achieved by using cell immobilization techniques where the cells can leak from the support, ensuring high yield of living, biologically active cells (Doleyres and Lacroix 2004).

Probiotics are living microorganisms capable of colonizing the human gut and conferring physiological benefits to the host. Probiotics are mostly administrated by dairy products sûch as yoghurts. Not all LABs fulfil the requirements for probiotics; mainly Lactobacillus and Bifidobacterium species are used and added as probiotic starters. The suggested consumption of probiotics is $10^{6}-10^{8}$ bacteria/g of food on a daily basis. Unfortunately, some probiotics, especially bifidobacteria, are very sensitive to the environmental changes during yoghurt fermentation, and the number of living bacteria decreases in the product. Bifidobacteria show also low survival rate during cold storage of dairy products; technologies ensuring stability of probiotics are therefore still a challenge for the food industry (Mitropoulou et al. 2013). Immobilization of probiotics can solve some problems by protecting cells from the $\mathrm{pH}$ and temperature changes, and increasing their viability and stability in fermented milk products, thus increasing their cell number. Another challenge for probiotics is the harsh environment in the human GI (gastrointestinal) tract. Low $\mathrm{pH}$ and protease activity in the gastric juice, followed by the emulsifying action of bile, cause cell death for the majority of microorganisms in the human GI tract. The number of surviving probiotics that are 
able to colonize the gut depends on their resistance to the above-mentioned circumstances. Immobilization can help the probiotics to survive. Different techniques and supports were used for the immobilization of LAB and probiotics with promising outcome. Delignified wheat bran was used for the adsorption of Lactobacillus casei as probiotic and L. bulgaricus as starter. The strains were immobilized separately and freeze-dried after the process. The freeze-dried, immobilized strains were used for yoghurt fermentation. Not only the cell viability was increased during storage at $4^{\circ} \mathrm{C}$ but also the aroma was more complex and preferred by tasters compared to traditionally produced yoghurt. The immobilized, frozen cells showed also higher survival in simulated gastric juice compared to non-immobilized ones (Terpou et al. 2017).

\subsubsection{Vinegar Production}

One of the oldest processes using the application of immobilized cells is vinegar production. Although chemical synthesis of acetic acid is cheap and can provide large quantities, only acetic acid fermented by microorganisms is allowed for human consumption. Acetic acid bacteria oxidize ethanol to acetic acid in a two-step process. The source of ethanol is mostly wine and the product is called vinegar. The traditional Orleans Process was used since 1670 in France where wooden casks were filled with wine and vinegar was added to start the process. The acetic acid bacteria flocculated and formed a thick slime on the walls of the barrel. In 1832 the Generator Process was developed where the bacteria were immobilized mainly on beech wood shavings. Fermentation was performed in open, large volume tanks. Although nowadays submerged cultures are used for vinegar production, the traditional method with immobilized cells is still used for manufacturing fine products (Bhat et al. 2014).

\subsubsection{Enzyme Production with Immobilized Cells}

In the modern food industry, enzymes are used in many fields to facilitate processes or to improve product quality. Microorganisms are cheap sources of enzymes because they can be cultured at industrial scale using agricultural waste materials as substrate. Lipases can be used in bidirectional actions, i.e. for hydrolysis or synthesis of lipids. Aspergillus niger is one of the best-known lipase producers. The spores of the mould were immobilized in sodium alginate beads and wheat bran was used as substrate. The alginate beads were reused in four subsequent fermentation cycles, giving higher yield than free cells. Because lipase is an intracellular enzyme, the application of immobilized whole cells can eliminate the steps of enzyme extraction and purification, making the enzymatic process more economical (Chandorkar et al. 2014).

\subsection{Immobilized Enzymes in the Food Industry}

As mentioned before, enzymes are used in many processes in the food industry. Since the purification of individual enzymes is a time-consuming multi-step process with high costs, sometimes crude extracts or whole, non-viable cells are used. Reusable enzymes can reduce the costs and make these processes economical. Immobilization of the enzymes offers the possibility of recovering the biocatalyst if that is needed. 
In some cases, the added enzyme becomes a part of the product, e.g. proteases or amylases used in improving the quality of wheat flour will remain in the baked product without the chance of reuse.

\subsubsection{Starch Industry and Production of Sweeteners}

Starch processing requires a lot of enzymes for the hydrolysis of starch and refining the products. Alfa amylases create malto-dextrins by partial hydrolysis of starch; thereof in the saccharification process glucoamylases create glucose syrup. Pullulanase debranches amylopectin by the hydrolysis of $\alpha 1-6$ bonds. Immobilization of $\alpha$-amylases, glucoamylases or pullulanase resulted in better thermal stability of the enzymes but Km values usually increased, showing that conformational changes during immobilization, especially by cross-linking or covalent binding of the enzymes, decreased enzyme activity (Contesini et al. 2013).

Isomaltulose (6-O- $\alpha$-D-glucopyronosyl-1-6-D-fructofuranose) is a sweetener with low cariogenicity and glycemic index, made from sucrose by the enzyme $\alpha$-glucosyltransferase. The enzyme is produced by several bacterial strains. Glucosyltransferase from Erwinia sp. was used for immobilization in Ca-alginate beads in the form of crude extract or whole cells lysed by ultrasonication (Kawaguti and Sato 2011). Lysed cells showed higher stability than the crude enzyme extract, and reached $53 \%-59 \%$ conversion of sucrose to isomaltulose.

In the production of the sweetener aspartame, aspartic acid and phenylalaninemethyl ester are linked together. E. coli entrapped in $\kappa$-carrageenan gel produces aspartic acid. In a few days after immobilization, E. coli die and the aspartase enzyme releases from the disintegrated cells and can be used for years as immobilized enzyme (Johnson-Green 2002).

The by-product of cheese fermentation is whey with high lactose content. $\beta$-galactosidase convert lactose into glucose and galactose, yielding a product sweeter than lactose. With the aid of $\beta$-galactosidase, whey can be converted to a sweet syrup usable in the food industry. Also, lactose in milk can be hydrolysed by the enzyme, resulting in lactose-free milk which has two advantages: people with lactose intolerance can drink this milk, and it can be used for production of ice-cream, condensed milk, etc., where lactose crystals would give a gritty texture. The enzyme is produced by several microorganisms. Enzyme from yeasts like Kluyveromyces lactis are used for the hydrolysis of milk lactose, while fungal $\beta$-galactosidases are used for the hydrolysis of acidic whey. The enzyme was immobilized by covalent binding or entrapment in $\kappa$-carrageenan or polyvinyl alcohol gels. The results are promising but there is a problem of microbial contamination in continuous systems. To avoid intermittent sanitation of the equipment, the industry shows interest in thermostable or cold-active $\beta$-galactosidases (Grosová et al. 2008).

\subsubsection{Production of Prebiotics}

Prebiotics are non-digestible food components that help maintain the healthy gut microflora. Galacto-oligosaccharides (GOS) contain usually 1-5 molecules of galactose and one glucose. GOS is synthetized by the reverse reaction of $\beta$-galactosidase, named transgalactosylation. This reaction needs high lactose concentration, high temperature, and lack of water. These circumstances are better achieved in immobilized 
systems where the enzyme is protected from heat and substrate inhibition. Maximum GOS production $(55 \% \mathrm{w} / \mathrm{w})$ was reached by $\beta$-galactoside, entrapped in chitosan beads, in a packed bed reactor (Grosová et al. 2008). Using magnetic polysiloxanepolyvinyl alcohol for immobilization of the enzyme, the biocatalyst was collected from the fermentation broth by magnetic field and was reused 10 times with only minimal loss of activity (Contesini et al. 2013).

\subsubsection{Immobilized Enzymes in the Production of Beverages}

Glucosidases are used for aroma liberation in wine because most of the volatile aroma compounds are linked to sugars by glycosidic bounds. $\beta$-glucosidase from Aspergillus sp. was immobilized in a sol-gel support, resulting in improved thermal and $\mathrm{pH}$ stability but also increased $\mathrm{Km}$ due to mass transfer limitations. To improve the productivity of juice pressing, immobilized pectin lyase from Penicillium italicum was immobilized by covalent binding to Nylon 6. Immobilization increased the storage and thermal stability of the enzyme (Contesini et al. 2013). Naringinase is used for debittering of citrus fruit juices. Fungal naringinase was immobilized on different supports like polyvinyl alcohol cryogels, cellulose triacetate nanofibres etc. Acetolactate in beer protracts the maturation to $2-12$ weeks. Using free or immobilized $\alpha$-acetolactate decarboxylase, maturation can be shortened to 1 day (Raveendran et al. 2018).

\subsection{Conclusion}

Immobilization of cells or enzymes in the food industry is mainly in the developing phase, although some applications are used in industrial scale (Table 8.1). The most promising area is the microencapsulation of probiotics that offers protection against

\section{TABLE 8.1}

Recent Examples on the Application of Immobilized Cells and Enzymes in the Production of Food Industrial Products, Beverages and Starter Cultures

\begin{tabular}{|c|c|c|c|}
\hline Product & $\begin{array}{l}\text { Microorganism } \\
\text { or Enzyme }\end{array}$ & Immobilization Method & References \\
\hline Wine & $\begin{array}{l}\text { S. cerevisiae } \\
\text { Oenococcus oeni }\end{array}$ & $\begin{array}{l}\text { Adsorption on plant wastes } \\
\text { Entrapment in Ca-alginate beads }\end{array}$ & $\begin{array}{l}\text { Genisheva et al. } \\
\text { (2014) }\end{array}$ \\
\hline Champa & S. cerevisiae & $\begin{array}{l}\text { Entrapment in coated } \\
\text { Ca-alginate beads }\end{array}$ & $\begin{array}{l}\text { Genisheva et al. } \\
\text { (2014) }\end{array}$ \\
\hline Beer & S. cerevisiae & Adsorption on plant wastes & Brányik et al. (2005) \\
\hline Starter cultures & $\begin{array}{l}\text { Lactic acid } \\
\text { bacteria }\end{array}$ & $\begin{array}{l}\text { Entrapment in food-grade } \\
\text { polymer beads }\end{array}$ & $\begin{array}{l}\text { Doleyres and } \\
\text { Lacroix (2004) }\end{array}$ \\
\hline Probiotics & $\begin{array}{l}\text { L. casei } \\
\text { Bifidobacteria }\end{array}$ & $\begin{array}{l}\text { Adsorption on delignified } \\
\text { wheat bran }\end{array}$ & Terpou et al. (2017) \\
\hline Lipase & A. niger & Entrapment in Ca-alginate beads & $\begin{array}{l}\text { Chandorkar et al. } \\
\text { (2014) }\end{array}$ \\
\hline Isomaltulose & Erwinia sp. & Entrapment in $\mathrm{Ca}$-alginate beads & $\begin{array}{l}\text { Kawaguti and Sato } \\
\text { (2011) }\end{array}$ \\
\hline Galacto-oligosaccharides & $\beta$-galactosidase & Entrapment in chitosan beads & $\begin{array}{l}\text { Grosová et al. } \\
\text { (2008) }\end{array}$ \\
\hline
\end{tabular}


the cell limiting factors arising during dairy production or in the human GI tract. Immobilization of enzymes or living or dead cells containing these enzymes make the processes cheaper and more feasible. In some cases, advantages of immobilization are contrasted by the mass transfer limitations caused by the support material; and choosing the suitable material is also a difficult issue, especially from a food safety point of view. Immobilization needs redesigning the process flow and equipment used but offers an economical production by reusing the biocatalyst. Taking pros and cons into account, we can say that immobilization will find its way in the food industry.

\section{ACKNOWLEDGEMENT}

MT thanks to the János Bolyai Research Scholarship of the Hungarian Academy of Sciences.

\section{REFERENCES}

Abdelmajeed, N. A., Khelil, O. A., Dania, E. N. 2012. Immobilization technology for enhancing bio-products industry. African Journal of Biotechnology 11:13528-13539.

Bhat, S.V., Akhtar, R., Amin, T. 2014. An overview on the biological production of vinegar. International Journal of Fermented Foods 3:139-155.

Bojsen, R. K., Scherz Andersen, K., Regenberg, B. 2012. Saccharomyces cerevisiaeA model to uncover molecular mechanisms for yeast biofilm biology. FEMS Immunology and Medical Microbiology 65:169-182.

Brányik, T., Silva, D. P., Vicente, A. A., Almeidae Silva, J. B., Teixeira J. A. 2005. Continuous beer fermentation with yeast immobilized on alternative cheap carriers and sensorial evaluation of the final product, Proceedings of the 2nd Mercosur Congress on Chemical Engineering-ENPROMER and 4th Mercosur Congress on Process Systems Engineering. Rio de Janeiro. [CD-ROM]. http://hdl.handle.net/1822/3520.

Chandorkar, V., Gomashe, A. V., Parlewar, S. 2014. Production of lipase by immobilized cells of Aspergillus niger. International Journal of Current Microbiology Applied Sciences 3:703-707.

Contesini, F. J., de Alencar Figueira, J., Kawaguti, H. Y. et al. 2013. Potential applications of carbohydrases immobilization in the food industry. International Journal of Molecular Sciences 14:1335-1369.

Cui, J., Hu, T., Qu, X., Zhang, L., Ding, Z., Dong, A. 2015. Plasmids from food lactic acid bacteria: Diversity, similarity, and new developments. International Journal of Molecular Sciences 16:13172-13202.

Doleyres, Y., Lacroix, C. 2004. Cell Immobilization for the dairy industry. http://citeseerx. ist.psu.edu/viewdoc/summary?doi=10.1.1.558.667.

Elakkiya, M., Prabhakaran, D., Thirumarimurugan, M. 2016. Methods of cell immobilization and its applications. International Journal of Innovative Research in Science, Engineering and Technology 5:5429-5433.

Flores-Maltos, A., Rodriguez-Duran, L. W., Renovato, J., Contreras, J. C., Rodriguez, R., Aguilar, C. N. 2011. Catalytical properties of free and immobilized Aspergillus niger tannase. Enzyme Research. doi:10.4061/2011/768183.

Genisheva, Z., Teixeira, J. A., Oliveira, J. M. 2014. Immobilized cell systems for batch and continuous winemaking. Trends in Food Science \& Technology 40:33-47.

Gibbs, B. F., Kermasha, S., Alli, I., Mulligan, C. N. 1999. Encapsulation in the food industry: A review. International Journal of Food Sciences and Nutrition 50:213-224. 
Groboillot, A., Boadi, D. K., Poncelet, D., Neufeld, R. J. 1994. Immobilization of cells for application in the food industry. Critical Reviews in Biotechnology 14:75-107.

Grosová, Z., Rosenberg, M., Rebroš, M. 2008. Perspectives and applications of immobilised $\beta$-galactosidase in food industry-A review. Czech Journal of Food Science 26:1-14.

Johnson-Green, P. 2002. Amino acids: Nutritional boost and flavor enhancers. In: $C R C$ Series in Contemporary Food Science, ed. P. Johnson-Green, 202-213. Boca Raton, FL, CRC Press.

Kawaguti, H. Y., Sato, H. H. 2011. Production of isomaltulose obtained by Erwinia sp. cells submitted to different treatments and immobilized in calcium alginate. Ciência e Tecnologia Alimentos 31:257-263.

Kerekes, E. B., Vidács, A., Török Jenei, J. et al. 2015. Essential oils against bacterial biofilm formation and quorum sensing of food-borne pathogens and spoilage microorganisms. In: The Battle Against Microbial Pathogens: Basic Science, Technological Advances and Educational Programs, Microbiology Book Series vol. 1(5), ed. A. Mendez-Vilas, 425-437. Badajoz, Spain, Formatex Research Center.

Kosseva, M. R. 2011. Immobilization of microbial cells in food fermentation processes. Food Bioprocess Technology 4:1089-1118.

Krisch, J., Buzás, Z., Dallmann, K., Tóth, M., Gimesi, I., Szajáni, B. 1995. Application of preformed cellulose beads as a support in cell immobilization. Biotechnology Techniques 9:221-224.

Krisch, J., Szajáni, B. 1996. Effects of immobilization on biomass production and acetic acid fermentation of Acetobacter aceti as a function of temperature and $\mathrm{pH}$. Biotechnology Letters 18:393-396.

Krisch, J., Szajáni, B. 1997. Ethanol and acetic acid tolerance in free and immobilized cells of Saccharomyces cerevisiae and Acetobacter aceti. Biotechnology Letters 19:525-528.

Mitropoulou, G., Nedovic, V., Goyal, A., Kourkoutas, Y. 2013. Immobilization technologies in probiotic food production. Journal of Nutrition and Metabolism 5:716861. doi:10.1155/2013/716861.

Raveendran, S., Parameswaran, B., Ummalyma, S. B., et al. 2018. Applications of microbial enzymes in food industry. Food Technology and Biotechnology 56:16-30.

Rouf, A., Kanojia, V, Naik, H. R. 2017. Cell immobilization: An overview on techniques and its applications in food industry. International Journal of Chemical Studies 5:1817-1824.

Sozer, N., Kokini, J. L. 2009. Nanotechnology and its applications in the food sector. Trends in Biotechnology 27:82-98.

Sutherland, I. W. 2001. The biofilm matrix —an immobilized but dynamic microbial environment. Trends in Microbiology 9:222-227.

Szajáni, B., Buzás, Zs., Dallmann, K., Gimesi, I., Krisch, J., Tóth, M. 1996. Continuous production of ethanol using yeast cells immobilized in preformed cellulose beads. Applied Microbiology and Biotechnology 46:122-125.

Terpou, A., Bekatorou, A., Kanellaki, M., Koutinas, A. A., Nigam, P. 2017. Enhanced probiotic viability and aromatic profile of yogurts produced using wheat bran (Triticum aestivum) as cell immobilization carrier. Process Biochemistry 55:1-10.

Weiss, J., Takhistov, P., McClements, J. 2006. Functional materials in food nanotechnology. Journal of Food Science 71:R107-R115. 
Willaert, R. G. 2011. Cell immobilization and its applications in biotechnology. In Fermentation Microbiology and Biotechnology, ed. E. M. T. El-Mansi, C. F. A. Bryce, B. Dahhou, S. Sanchez, A. L. Demain, A. R. Allman, 314-360. Boca Raton, FL: CRC Press.

Zur, J., Wojcieszynska, D., Guzik, U. 2016. Metabolic responses of bacterial cells to immobilization. Molecules 21 (7): 958. doi:10.3390/molecules21070958. 